\section{Acute injury care: the oft-forgotten prequel to rehabilitation and return to sport}

\author{
Stephen Mutch 지 , ${ }^{1,2}$ Rebecca Knight, ${ }^{3}$ Philip Glasgow ${ }^{4,5}$
}

Physiotherapists working in sport are expected to manage injuries from the moment they occur. When witnessing live sport, the physiotherapist watches for signs of trauma, overstretching or other unusual patterns of movement that can guide decision-making in a way that is of greatest help to the athlete. Regular training ensures that physiotherapists work as part of an inter-disciplinary team to provide treatment and timely removal from a field of play when necessary. Recognising important clues such as the degree of distress and injury mechanism can help shape the initial assessment and management based on training, experience and pattern recognition.

\section{ACUTE MANAGEMENT IN DIFFERENT CONTEXTS}

This BJSM edition focuses on Acute Management, rather than Rehabilitation or Return to Sport that more frequently headline conferences and symposia, or are commonly found within journal pages, blogs and across social media. Acute management and athlete assessment are discussed in an assortment of varied contexts. Dr Charles Pedlar discusses medical encounters in recreational running events, such as the popular and global Parkrun (see page 1420), while Yuri Hosokawa and colleagues present expert recommendations for the acute management of heat stress (see page 1405). The relationship of technical positions and injury in rugby union is described by Vincent Meintjes and colleagues (see page 1411).

\section{${ }^{1}$ Medical, Ireland Rugby Football Union, Dublin, Ireland ${ }^{2}$ Affiliate Researcher, School of Life Sciences, Edinburgh Napier University, Edinburgh, UK \\ ${ }^{3}$ High Performance Centre, University of Birmingham, Birmingham, B15 2TT, UK \\ ${ }^{4}$ Medical, Irish Rugby Football Union, Dublin, Ireland ${ }^{5}$ School of Sport, Ulster University - Jordanstown Campus, Newtownabbey, UK}

Correspondence to Rebecca Knight, High Performance Centre, University of Birmingham, Birmingham B15 2TT, UK; rebeccarknight@gmail.com

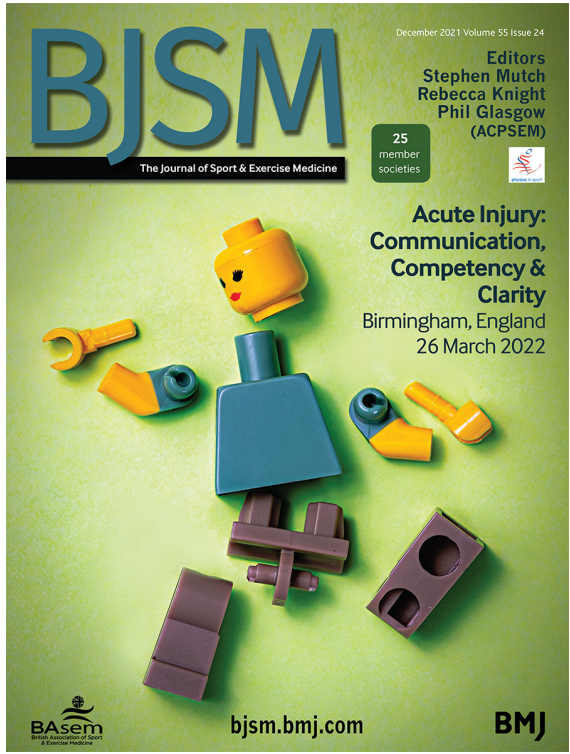

UNDERSTANDING CONCUSSION

The complex and varied presentation of, and recovery from, concussion is presented in three different papers that consider unique salivary signatures (see page 1395), gender differences (see page 1387) and age (see page 1427). These papers by Valentina di Pietro, Christina L. Master, Mohammad Nadir Haider and their colleagues offer a greater understanding of a complex injury that will further inform the classification and relationship of head injury to management.

Sport should be a safe haven for inclusion. Inequalities in sport include systemic discrimination against marginalised groups and the promotion of undesirable or unethical behaviours including disrespect, harrassment or abuse. There is need for greater understanding of environments that have been established or deliberately engineered for the promotion of hierarchy based on race/ethnicity, gender, perceived ability, wealth or age. An insightful editorial (see page 1385) and accompanying infographic (see page 1439) by TuakliWosornu highlight key issues targeting entrenched status and potential athlete abuse. These valuable resources and those available in the BJSM e-edition on

\section{SPORT AS A SAFE HAVEN}

\#SportsEquity (https://bjsm.bmj.com/ pages/bjsm-e-edition-sportsequity/) should serve to remind each of us to be vigilant and to 'consciously and deliberately expose and dismantle societal biases in our field of Sport and Exercise Medicine.'

Finally, it is great to see the excellent $\mathrm{PhD}$ work of physiotherapist Mark Matthews in print (see page 1436). He conducted a multicentre randomised clinical trial on patellofemoral pain-a condition often encountered in the clinic, at training or in the hospital outpatient department. $\mathrm{He}$ focused on foot mobility, and whether this evaluation could affect the selection of two frequently recommended but essentially different approaches to management: an exercise-based proposal targeting the proximal hip muscles, or the more distal solution in supplying foot orthoses.

\section{PHYSIOS IN SPORT CONFERENCE: 'ACUTE INJURY: COMMUNICATION, COMPETENCY AND CLARITY'}

At last, there are opportunities for us to meet face to face again at conferences. The Association of Chartered Physiotherapists in Sport \& Exercise Medicine (ACPSEM) is thrilled to be able to hold a Spring Conference this March in Birminghamthe host city for the 2022 Commonwealth Games. With medical volunteers for the Games giving up their time to be by the track, at the gymnasia, in training venues, poolside, ringside and pitchside, it is imperative that they have training and understanding of immediate care on the field of play.

This Conference has at its core the desire to support physios involved in sport. Deliberately selecting 'Acute Injury: Communication, Competency and Clarity' as the theme, each session is clearly matched to the International Federation of Sports Physical Therapists competency statements and standards. This event will ensure targeted continuing professional development is more accessible for attendees: there are carefully aligned parallel sessions for volunteers as well as those more experienced in multisport events, which will ensure plenty of takeaways appropriate for everyone at any stage of their personal Continuous Professional Development pathway or individual portfolio. Not-to-miss keynote sessions will consider the games landscape next summer from the volunteer Medical Services Department of Birmingham 2022, the evolving landscape of traumatic brain injury in sport, and a closing keynote with Melrose Stewart MBE describing 


\section{Warm up}

cultural competency in sport in a tangible and understandable manner.

There will be an unusual opportunity for acute injury management to be frankly debated and discussed at an additional bolt-on event the evening before, when ACPSEM guests will reflect on the ten years since the London 2012 Olympics, and where sport is heading across fields such as mental health, media pressure and technology. Healthcare professionals from any sports and backgrounds should consider joining these presenters, whom will personally share what they were involved with a decade ago, what they have done and seen since in their various areas of work and interest, and how they view the future sporting landscape!

Contributors The authors represent a BJSM Member Organisation SubGroup presenting a Warm-Up to the UK Physios in Sport Special Edition.

Funding The authors have not declared a specific grant for this research from any funding agency in the public, commercial or not-for-profit sectors.

Competing interests None declared.

Patient consent for publication Not applicable.
Provenance and peer review Commissioned; internally peer reviewed.

(C) Author(s) (or their employer(s)) 2021. No commercial re-use. See rights and permissions. Published by BMJ.

\section{Check for updates}

To cite Mutch S, Knight R, Glasgow P. Br J Sports Med 2021;55:1381-1382.

Accepted 4 November 2021

Br J Sports Med 2021:55:1381-1382.

doi:10.1136/bjsports-2021-105167

ORCID iD

Stephen Mutch http://orcid.org/0000-0002-1960-1573 